\title{
Dung in the dumps: what we can learn from multi-proxy studies of archaeological dung pellets
}

\author{
Daniel Fuks ${ }^{1,2}\left(\mathbb{0} \cdot\right.$ Zachary C. Dunseth $^{3}(\mathbb{0}$
}

Received: 30 November 2019 / Accepted: 14 October 2020 / Published online: 15 November 2020

(c) The Author(s) 2020

\begin{abstract}
A key question in archaeobotany concerns the role of herbivore dung in contributing plant remains to archaeobotanical assemblages. This issue has been discussed for at least 40 years and has motivated several archaeobotanical studies on identifying dung-derived deposition of plant remains. Meanwhile, microarchaeological methods have developed and continue to be developed for detecting dung in archaeological sediments, and multi-proxy methodologies are being used to study the botanical components of dung-associated sediments. Combining these approaches, the authors recently led a study incorporating different botanical proxies (seeds, pollen, phytoliths) with geoarchaeological sedimentary analysis to compare dung pellets and associated sediments. This approach presents a new way to gauge the contribution of dung-derived plant remains in archaeobotanical assemblages, which is further explored in this follow-up paper. The present paper further highlights how multi-proxy archaeobotanical investigation of individual dung pellets can provide information on seasonality, grazing range and herding practices. Their short production and deposition time make herbivore dung pellets time capsules of agropastoral activity, a useful spatio-temporal unit of analysis, and even a type of archaeological context in their own right. Adding different biomolecular and chemical methods to future multi-proxy archaeobotanical investigation of herbivore dung will produce invaluable high-resolution reconstructions of dung microbiomes. Ultimately, unpacking the contents of ancient dung pellets will inform on the species, physical characteristics, diet, niche, and disease agents of the ancient pellets' producers. Expanded datasets of such dung-derived information will contribute significantly to the study of ecosystem transformation as well as the long-term development of agriculture and pastoralism.
\end{abstract}

Keywords Archaeobotany $\cdot$ Palaeoethnobotany $\cdot$ Geoarchaeology $\cdot$ Archaeological dung $\cdot$ Coprolites $\cdot$ Multi-proxy study

Communicated by G. Fiorentino.

Electronic supplementary material The online version of this article (https://doi.org/10.1007/s00334-020-00806-x) contains supplementary material, which is available to authorized users.

Daniel Fuks

daniel.fuks@biu.ac.il

$\triangle$ Zachary C. Dunseth

zachary_dunseth@brown.edu

1 Archaeobotany Lab, Martin (Szusz) Land of Israel and Archaeology Department, Bar-Ilan University, Ramat-Gan 5290002, Israel

2 McDonald Institute for Archaeological Research, Department of Archaeology, University of Cambridge, Downing St, Cambridge CB2 3ER, UK

3 Joukowsky Institute for Archaeology and the Ancient World, Brown University, 60 George St, Providence, RI 02912, USA

\section{Introduction}

Considering the centrality of livestock to agricultural and pastoral societies, there is still much to learn from the archaeology of herbivore dung, studied intensively now for decades. Dung is presumed to have been collected by the earliest hunter-gatherers and its use by humans for fuel has been hypothesized as a driving factor in prehistoric migrations and domestication processes (Rhode et al. 2003, 2007; Spengler and Mueller 2019). As a byproduct of livestock rearing, dung was used for building material, fertilizer and fuel in ancient and traditional societies, and is relatively common in archaeological assemblages. Hence, herbivore dung is a valuable archaeological artifact/ecofact that can provide information on ancient daily life, economy and ecology at a site and its vicinity (e.g. Miller 1984a; ShahackGross 2011). Grounded in the authors' recent contribution to this topic (Dunseth et al. 2019), the following paper traces 
trajectories and future directions of herbivore dung research in archaeology as it relates specifically to vegetation history and archaeobotany.

Archaeological herbivore dung has been studied in different ways and with various research goals in mind. In the field of archaeobotany, a key question concerns the role of herbivore dung in contributing seeds to archaeobotanical assemblages. This has yielded decades of discussion (partially summarized in Allen 2019; Spengler 2019; and below). Multi-proxy methodologies are now being used to study the botanical components of dung-associated sediments (e.g. Baeten et al. 2018; Smith et al. 2019; Rotunno et al. 2019). The present authors recently led a study combining botanical proxies (seeds, pollen, phytoliths) with geoarchaeological methods to compare the botanical contents of dung pellets and associated sediments (Dunseth et al. 2019). This approach suggests a new way to gauge the contribution of dung-derived plant remains to archaeobotanical assemblages, and move beyond this long-standing issue. As has long been the case with human coprolites (see recent review, Shillito et al. 2020), archaeological herbivore dung pellets are increasingly being studied for the information contained within them. Hence, while also motivated by the question of dung-derived plant remains, our study on dung pellets in the ancient rubbish dumps of Shivta in Israel's Negev desert (Dunseth et al. 2019) went beyond that debate by demonstrating the potential of ancient dung pellets as time capsules of agropastoral activity. We found that individual dung pellets can provide important information on seasonality, grazing range, herding practices, and potentially much more. Their short production and deposition time make herbivore dung pellets a useful spatio-temporal unit of analysis, and even a type of archaeological context in their own right.

These insights were confirmed and enhanced at the 2019 International Work Group for Palaeoethnobotany (IWGP) meeting in Lecce, Italy, where we presented our finds from the Shivta pellets. Intact archaeological herbivore dung pellets are even more common than the literature suggests, and a synopsis of their potential would be useful for archaeologists, archaeological scientists, and researchers in associated disciplines. This paper surveys the research on archaeological herbivore dung, with an emphasis on insights from our own recent study and directions for future research. Our focus is on the retrieval of information related to vegetation history and archaeobotany from herbivore dung. For nonspecialists, we address the question of how archaeologists can make the most of dung pellet finds.

\section{Herbivore dung research in archaeobotany: a brief review}

The question of dung as a source of plant remains in archaeological assemblages has been studied for at least 40 years. In her early work in Iran, Naomi Miller raised the possibility of dung-derived plant remains as a major contributor to archaeological assemblages. This was based on ethnographic observations of dung cakes used as fuel, and corroborating archaeobotanical finds (Miller 1977, 1981, 1982, 1983, 1984a, b; also Bottema 1984). Hence, the ratios of dung and/or seeds to charcoal in archaeological assemblages may be an indicator for the centrality of dung as a fuel source and, in certain contexts, a sign of deforestation (Miller 1988; Miller and Marston 2012; Allen 2019). These studies raised awareness on the importance of herbivore dung and dung cake preparation for ethnoarchaeological models of crop production, processing, and taphonomy (Dennell 1972, 1974; Hillman 1973, 1981, 1984; more recently, Wallace and Charles 2013; Fuller et al. 2014; Hansen et al. 2017). Miller (1984b) also noted the difficulty of distinguishing between "grain incorporated in dung and grain attached to straw which is used in the manufacture of dung cakes", and of generally distinguishing between the use of cereal grains for food and fodder in archaeological contexts. Meanwhile, Miller and Smart (1984) suggested four conditions in which dung should be considered a possible source of plant remains: (1) scarcity of wood in the site environment; (2) presence of suitable dung-producing animals; (3) presence of burned dung fragments or seeds likely to reflect animal consumption rather than human processing; and (4) archaeological contexts identified as hearths or hearth waste. Focusing on how to recognize dung-derived plant remains, Charles (1998) noted that conditions (1) and (2) above explain why dung might be used as fuel, rather than identifying assemblages as such. In addition, "seeds likely to reflect animal consumption" in condition (3) may involve (faulty) retrospective reasoning on what constituted animal fodder. Finally, recovery of dung and plant remains in hearth contexts (condition 4) confirms the burning of fuel but does not confirm that the plant remains were deposited via dung. Charles (1998) proposed that archaeobotanical indicators for dung-derived plant remains in archaeological assemblages should include: (i) divergence between crop harvest seasons on one hand and on the other hand, wild species' fruiting season and seasonal palatability; (ii) significant presence of plant species not associated with crop processing; and (iii) a high ratio of chaff to grain seeds.

Meanwhile, debate on dung as a source of plant remains acquired a larger audience beyond the archaeobotany community with Miller's (1996) article in Current Anthropology. Miller challenged interpretations of certain prehistoric 
archaeobotanical assemblages (Ali Kosh and Abu Hureyra) as representing human diet, suggesting that they may well have derived from herbivore dung used as a fuel source. This was forcefully countered by Hillman et al. (1997) with a rebuttal from Miller (1997), but the problem of empirically distinguishing human and animal consumption in the archaeobotanical record remained. The first volume of the Journal of Environmental Archaeology (1998) was devoted to the archaeology of animal fodder, whereas the first issue of that same journal's 2013 volume was devoted to the bioarchaeology of animal dung. Adopting a macrocosmic archaeobotanical approach, Fuller et al. (2014) argue that plant-food processing, rather than dung, is the main source of plant remains in archaeobotanical assemblages generally. Fuller et al. (2014, p. 189) nonetheless advise site-specific analysis of "the relative amount of noise added by dung burning" in the style of Charles (1998) or through a multiproxy approach, e.g. by combining phytolith and macrobotanical analyses.

Recent macroremains research on the taphonomy and identification of dung-derived archaeobotanical assemblages includes several experimental studies focused on the survivability of macroscopic plant parts in the sheep/goat gut (Valamoti and Charles 2005; Spengler et al. 2013; Valamoti 2013; Wallace and Charles 2013). Indicators of dungderived archaeobotanical assemblages based on these studies and not explicitly discussed earlier by Miller and Smart (1984) nor Charles (1998) include: (a) relative absence (or serious deforming) of cereal grains; (b) glume bases that are vertically split or roughened at the surface; (c) a high degree of fragmentation and unidentifiable non-wood fragments; and (d) plant species from ecotopes favored by livestock. One bias in these studies has been a focus on sheep/goat dung. Survivability of seeds and other plant parts differs among herbivore species whose dung is used for fuel, which range worldwide from Andean camelids (Winterhalder et al. 1974) to Mongolian yaks (Rhode et al. 2007). Even among the herbivore domesticates of southwest Asia, significant differences abound between the diet and digestion, and therefore survivability, of plant matter in bovine, ovicaprine, equine, and camelid gastrointestinal systems (Anderson and Ertug-Yaras 1998; Hastorf and Wright 1998; Tsartsidou et al. 2008). However, since these animals are often kept at the same site, and their dung may be combined in fuel use, many ethnoarchaeological studies make no species-specific distinction (Gur-Arieh et al. 2013; Spengler et al. 2013; Portillo et al. 2017).

Pollen analyses of sheep/goat dung preserved by waterlogging (Akeret et al. 1999; Kühn et al. 2013 and references therein) and desiccation (Spaulding 1974; Babenko et al. 2007; Marinova et al. 2013; Ben-Yosef et al. 2017) were performed prior to, and irrespective of, the Near Eastern dung fuel debate. This is understandable considering that pollen is unlikely to be preserved in dung that has been burned for fuel. Interestingly, at least one study of pollen and macroremains in dung pellets and associated sediments seems to show that dung contributed only a subset of the plant taxa identified in the sediments, but this was not specifically addressed by the author (Karg 1998).

Finally, different combinations of micromorphological, palynological, phytolith, macroremain and other proxies are being used to study the botanical components of dungassociated sediments (e.g. di Lernia 2001; Shahack-Gross et al. 2003, 2014; Shahack-Gross and Finkelstein 2008; Delhon et al. 2008; Savinetsky et al. 2012; Kühn et al. 2013; Baeten et al. 2018; Smith et al. 2019; Portillo et al. 2019). A few studies have examined botanical contents of individual dung pellets (Karg 1998; Rotunno et al. 2019; Dalton and Ryan 2020). As far as we are aware, prior to Dunseth et al. (2019) no previous study compared plant remains from dung pellets with plant remains from associated archaeological sediments.

\section{The impact of geoarchaeological identification of archaeological dung}

Geoarchaeological methods for identifying and characterizing archaeological contexts are well-developed, and need little introduction here (e.g. Matthews 2010; Weiner 2010; Mentzer 2014; Nicosia and Stoops 2017; Karkanas and Goldberg 2019). Among these, methods for differentiating archaeological ash, dung, and dung-derived sediments have been reviewed most thoroughly by Shahack-Gross (2011), and thus will only be briefly discussed here. Much work has been done on identifying dung remains through chemical analyses, including phosphate and potassium enrichments/ depletions, and nitrogen and carbon isotopes (see ShahackGross 2011; Spengler 2019). However, such chemical indicators are often limited proxies, due to preservation issues including the potential for other organic/inorganic inputs and post-depositional diagenesis (e.g. presence of bone or decayed organic matter) (Evershed et al. 1997; ShahackGross 2011). Additional proxies for detecting dung include urine salts (Abell et al. 2019), dung-related fauna and intestinal parasites (Schelvis 1992; Buckland and Buckland 2019; Camacho et al. 2020), coprophilous fungi (Perrotti and van Asperen 2019), lipid biomarkers (Evershed et al. 1997; Bull et al. 1999, 2002; Shillito et al. 2011) and the combination of phytolith and chemical signatures (Lancelotti and Madella 2012). Phytolith concentrations and/or morphologies have also been used to identify dung remains, although this has methodological issues (Shahack-Gross et al. 2005).

Geo-ethnoarchaeological studies, especially micromorphological investigations since the 1980s, have helped to define a variety of animal dung-related archaeological 
deposits including characterization of pellets of a variety of herbivores (Brönnimann et al. 2017), dung fuel (Gur-Arieh et al. 2013; Portillo et al. 2017, 2020), and stabling enclosures (Wattez et al. 1990; Macphail et al. 1997; ShahackGross et al. 2003; Milek 2012; Shahack-Gross 2017). Many of these studies focused on dung (faecal) spherulites, direct indicators of animal dung in archaeological sediments. First identified by Brochier (1983), dung spherulites are microscopic remains $(5-25 \mu \mathrm{m})$ made up of radially-oriented acicular crystallites, which display low-order interference colours with a distinctive extinction cross under cross-polarized light (Canti and Brochier 2017a). They are known to form in the small intestines of a number of animal species, most abundantly in ruminants (Canti 1997, 1998, 1999; Goren 1999; Korstange 2005; see summary and Table 1 in GurArieh and Shahack-Gross 2020). While their exact formation mechanism is unclear, in archaeological sediments they appear to be composed of highly-disordered calcite (Dunseth and Shahack-Gross 2018).

Dung spherulites tend to be best-preserved in caves and rockshelters (e.g. Brochier et al. 1992; Macphail et al. 1997; Polo-Díaz et al. 2016), rapidly buried sediments (ShahackGross et al. 2014; Butler et al. 2020), or (semi-) arid environments (e.g. Matthews et al. 1996; Shahack-Gross et al. 2005; Shahack-Gross and Finkelstein 2008; Portillo et al. 2014; Dunseth et al. 2018; Dalton and Ryan 2020; compare to tropical environments, e.g. Gur-Arieh et al. 2019a). However, they are prone to dissolution in acidic and even neutral environments due to their chemical composition and large surface-area to volume ratios (Brochier et al. 1992; Canti 1999; Gur-Arieh et al. 2014). In addition, dung spherulites begin to decompose when exposed to temperatures between 300 and $400{ }^{\circ} \mathrm{C}$ (Canti and Nicosia 2018) and are completely destroyed by $650-700{ }^{\circ} \mathrm{C}$ (Shahack-Gross 2011; Gur-Arieh et al. 2019b). Thus, their absence in archaeological sediments does not necessarily indicate the absence of dung or dung-derived material.

Differentiation between wood and dung ash, or mixtures of the two, can often be determined via geoarchaeological methods. Easily distinguishable microremains indicative of wood ash are calcitic pseudomorphs after calcium oxalate crystals, known as ash pseudomorphs (Gur-Arieh and Shahack-Gross 2020). Calcium oxalates form in various plant tissues of many dicotyledonous as well as a few monocotyledonous species (Franceschi and Horner 1980). Production is governed by environmental conditions (Franceschi and Nakata 2005). Typical crystal shapes in dicots include druzes, rhombs, raphides, styloids and prisms, usually between 10 and $50 \mu \mathrm{m}$ (Franceschi and Horner 1980; Canti 2003; Canti and Brochier 2017b; Gur-Arieh and Shahack-Gross 2020). Exposure of these calcium oxalate crystals to temperatures above $450{ }^{\circ} \mathrm{C}$ transforms them into calcitic (ash) pseudomorphs. Utilizing ethnoarchaeological data from
Uzbekistan, Gur-Arieh et al. (2013) developed the Pseudomorph to Spherulite Ratio (PSR), which has been used by a number of researchers to differentiate between wood and dung fuels from archaeological hearths and ash contexts (Gur-Arieh et al. 2014; Dunseth et al. 2016, 2018; EliyahuBehar et al. 2017; Butler et al. 2020). In some ways this is analogous to Miller's $(1982,1988)$ original seed:charcoal ratios used to identify dung assemblages, although it is a more direct approach. It must be noted, however, that PSR is formulated in a way that makes it sensitive to the presence of dung spherulites, and assumes wood fuels that produce high concentrations of ash pseudomorphs, which is not universal (see below). Application of the above geoarchaeological methods at Shivta allowed characterization of the archaeological deposits, their formation processes (Dunseth et al. 2019; Butler et al. 2020), and subsequently the origin of the associated archaeobotanical remains.

\section{Dung in the dumps of Shivta}

\section{A test-case for dung-derivation}

Early Islamic (Umayyad, ca. 650-750 CE) rubbish middens from Shivta in Israel's Negev desert, excavated in 2016, met all four conditions proposed by Miller and Smart (1984) for possible dung-related plant remains: (1) Shivta is located in the arid Negev desert (WSG84: $34.6307^{\circ} \mathrm{E}$, $30.8810^{\circ} \mathrm{N} ;<100 \mathrm{~mm}$ mean annual precipitation) where the few trees growing are confined to wadi beds; (2) archaeozoological evidence suggests a high proportion of sheep/ goats (Marom et al. 2019); (3) sheep/goat dung pellets were evident during excavation (Fig. 1) and the archaeobotanical assemblage included seeds of wild plants not associated with cultivated landscapes (Table 1); and (4) these rapiddeposition middens were apparently produced by dumping of domestic hearth waste. In addition, initial mineralogy and microremains concentrations (especially PSR) suggested dung-derived sediments (Table 2). However, the ubiquity of well-preserved cereal grains as well as a variety of delicate plant parts (ESM Table 1) suggested that the archaeobotanical assemblage on the whole was not directly dung-derived.

These observations presented an ideal opportunity to test the possibility of dung-derived plant remains, through a multi-proxy comparison of archaeological dung pellet contents and those of associated midden sediments. We wondered, how do the plant remains within dung pellets compare with those of the rest of the middens? What can plant remains in dung pellets tell us about their creators' diets and grazing practices? Finally, how do different archaeobotanical proxies complement one another in the study of dung?

To use dung pellets as time capsules for ancient agropastoralism, it is crucial to work with secure contexts 
Table 1 Species and synanthropy by context

\begin{tabular}{|c|c|c|c|c|c|c|}
\hline Species* & Synanthropic level & $\begin{array}{l}\text { Modern } \\
\text { pellets }\end{array}$ & L. 162 pellets & L. 501 pellets & $\begin{array}{l}\text { L. } 162 \\
\text { sediment }\end{array}$ & $\begin{array}{l}\text { L. } 501 \\
\text { sediment }\end{array}$ \\
\hline Hordeum vulgare ssp. hexastichum & Cultivated & . & . & . & $\checkmark$ & $\checkmark$ \\
\hline Triticum aestivum s.l & Cultivated & . & . & . & $\checkmark$ & $\checkmark$ \\
\hline Triticum turgidum s.l & Cultivated & . & . & . & $\checkmark$ & $\checkmark$ \\
\hline Vicia ervilia & Cultivated & . & . & . & $\checkmark$ & $\checkmark$ \\
\hline Lens culinaris & Cultivated & . & . & . & $\checkmark$ & $\checkmark$ \\
\hline Trigonella foenum-graecum/berythea** & Cultivated & . & . & . & $\checkmark$ & . \\
\hline Ficus carica & Cultivated & . & $\cdot$ & . & $\checkmark$ & . \\
\hline Phoenix dactylifera & Cultivated & . & . & . & $\checkmark$ & $\checkmark$ \\
\hline Punica granatum & Cultivated & . & . & . & $\checkmark$ & . \\
\hline Vitis vinifera & Cultivated & . & . & . & $\checkmark$ & $\checkmark$ \\
\hline Chenopodium murale & Obligate synanthropic & $\checkmark$ & . & . & $\checkmark$ & . \\
\hline Lolium temulentum & Obligate synanthropic & . & . & . & $\cdot$ & $\checkmark$ \\
\hline Malva parviflora/oxyloba & Mostly synanthropic & . & . & . & $\checkmark$ & $\checkmark$ \\
\hline Phalaris paradoxa & Mostly synanthropic & . & . & . & $\checkmark$ & $\checkmark$ \\
\hline Spergula fallax & Mostly synanthropic & . & . & . & $\checkmark$ & . \\
\hline Brachypodium distachyon & Equally synanthropic \& natural & $\cdot$ & . & . & $\checkmark$ & $\checkmark$ \\
\hline Cynodon dactylon & Equally synanthropic \& natural & $\checkmark$ & $\checkmark$ & $\checkmark$ & $\checkmark$ & $\checkmark$ \\
\hline Glebionis coronaria & Equally synanthropic \& natural & . & . & . & $\checkmark$ & . \\
\hline Hordeum glaucum & Equally synanthropic \& natural & . & . & · & $\cdot$ & $\checkmark$ \\
\hline Lolium rigidum & Equally synanthropic \& natural & . & . & . & $\cdot$ & $\checkmark$ \\
\hline Anagallis arvensis & Mostly natural & · & $\checkmark$ & . & $\checkmark$ & $\checkmark$ \\
\hline Andrachne telephioides & Mostly natural & $\cdot$ & . & . & $\checkmark$ & . \\
\hline Anthemis pseudocotula & Mostly natural & $\checkmark$ & . & . & . & $\checkmark$ \\
\hline Astragalus callichrous & Mostly natural & $\checkmark$ & . & . & $\cdot$ & $\cdot$ \\
\hline Avena barbata & Mostly natural & . & . & . & . & $\checkmark$ \\
\hline Avena sterilis & Mostly natural & $\cdot$ & . & . & $\checkmark$ & $\checkmark$ \\
\hline Caylusea hexagyna & Mostly natural & . & . & . & $\checkmark$ & $\checkmark$ \\
\hline Centaurea pallescens & Mostly natural & $\checkmark$ & . & . & . & . \\
\hline Echium angustifolium & Mostly natural & . & . & . & . & $\checkmark$ \\
\hline Emex spinosa & Mostly natural & . & . & . & $\checkmark$ & $\checkmark$ \\
\hline Erucaria microcarpa & Mostly natural & . & . & . & . & $\checkmark$ \\
\hline Fumaria parviflora/densiflora & Mostly natural & . & . & $\cdot$ & $\checkmark$ & $\checkmark$ \\
\hline Galium aparine & Mostly natural & . & . & . & $\checkmark$ & . \\
\hline Mesembryanthemum nodiflorum & Mostly natural & . & . & . & $\cdot$ & $\checkmark$ \\
\hline Neslia apiculata & Mostly natural & . & . & . & $\checkmark$ & . \\
\hline Phalaris minor & Mostly natural & . & . & . & $\checkmark$ & $\checkmark$ \\
\hline Pulicaria incisa & Mostly natural & . & $\checkmark$ & . & . & . \\
\hline Silene colorata/decipiens & Mostly natural & . & . & . & $\checkmark$ & $\checkmark$ \\
\hline Trigonella arabica & Mostly natural & . & . & . & . & $\checkmark$ \\
\hline Vaccaria hispanica & Mostly natural & . & . & . & . & $\checkmark$ \\
\hline Vicia sativa & Mostly natural & . & . & . & . & $\checkmark$ \\
\hline Adonis dentata & Obligate natural & . & . & . & $\checkmark$ & $\checkmark$ \\
\hline Aizoon hispanicum & Obligate natural & $\checkmark$ & $\checkmark$ & · & $\checkmark$ & $\checkmark$ \\
\hline Arnebia decumbens & Obligate natural & $\cdot$ & . & . & $\checkmark$ & $\checkmark$ \\
\hline Astragalus tribuloides/asterias & Obligate natural & $\checkmark$ & . & $\cdot$ & . & $\cdot$ \\
\hline Bassia muricata & Obligate natural & . & . & . & $\checkmark$ & . \\
\hline Buglossoides tenuiflora & Obligate natural & . & . & . & . & $\checkmark$ \\
\hline Cutandia memphitica/dichotoma & Obligate natural & . & . & . & $\cdot$ & $\checkmark$ \\
\hline Gypsophila capillaris & Obligate natural & . & . & . & $\checkmark$ & . \\
\hline
\end{tabular}


Table 1 (continued)

\begin{tabular}{|c|c|c|c|c|c|c|}
\hline Species* & Synanthropic level & $\begin{array}{l}\text { Modern } \\
\text { pellets }\end{array}$ & L. 162 pellets & L. 501 pellets & $\begin{array}{l}\text { L. } 162 \\
\text { sediment }\end{array}$ & $\begin{array}{l}\text { L. } 501 \\
\text { sediment }\end{array}$ \\
\hline Malva aegyptia & Obligate natural & . & $\checkmark$ & . & . & . \\
\hline Medicago astroites & Obligate natural & . & . & . & $\checkmark$ & $\checkmark$ \\
\hline Melilotus sulcatus & Obligate natural & . & . & . & $\checkmark$ & . \\
\hline Plantago chamaepsyllium/notata & Obligate natural & . & . & . & $\checkmark$ & $\checkmark$ \\
\hline Plantago ovata & Obligate natural & $\checkmark$ & . & . & $\checkmark$ & . \\
\hline Retama raetam & Obligate natural & $\checkmark$ & . & . & . & . \\
\hline Schismus arabicus/barbatus & Obligate natural & $\checkmark$ & . & . & . & . \\
\hline Scorpiurus muricatus & Obligate natural & $\checkmark$ & . & . & . & $\checkmark$ \\
\hline Stipa capensis & Obligate natural & $\checkmark$ & . & . & . & . \\
\hline Tamarix aphylla*** & Obligate natural & . & . & . & $\checkmark$ & $\checkmark$ \\
\hline cf. Trifolium campestre & Obligate natural & . & $\checkmark$ & . & $\checkmark$ & . \\
\hline cf. Trifolium tomentosum & Obligate natural & $\checkmark$ & . & . & . & . \\
\hline Thymelaea hirsuta & Obligate natural & . & . & . & $\checkmark$ & $\checkmark$ \\
\hline Total & & 13 & 6 & 1 & 39 & 39 \\
\hline
\end{tabular}

*Species names follow Danin and Fragman-Sapir (2020+), accessible at https://flora.org.il

**Although $T$. berythea is a wild species, it does not grow wild in the Negev; therefore we consider the T. foenum-graecum/berythea find to be cultivated

***We previously reported on an additional Tamarisk species (T. nilotica s.1.) from Early Islamic Shivta (Dunseth et al. 2019) but these nonsegmented Tamarisk leaves lacking the characteristic salt glands of $T$. aphylla turned out to be remains of $T$. aphylla inflorescences rather than $T$. nilotica s.l. stems with leaves

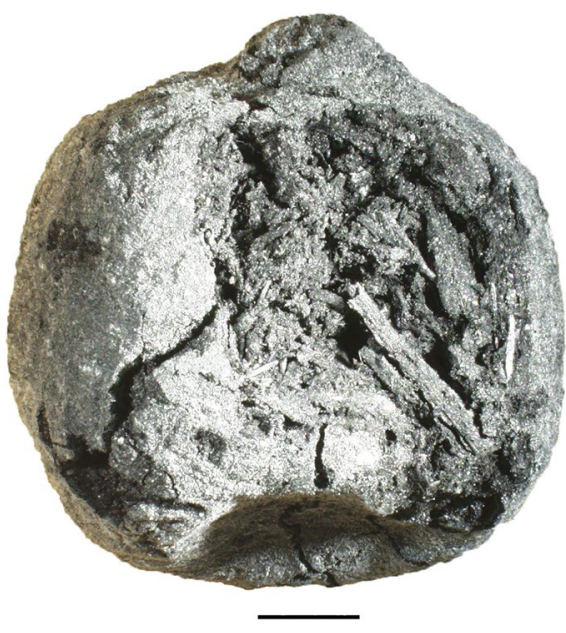

Fig. 1 An archaeological dung pellet retrieved from an Early Islamic midden in Shivta (Area K1, Locus 165, Basket 1673); scale bar $=2 \mathrm{~mm}$

and chronologies, precluding later intrusions. The location of the Umayyad Shivta middens in abandoned houses, the inclusion of mixed cultural material, faunal and macrobotantical remains, and both charred and uncharred pellets, broadly indicated secondary deposition in the contexts studied, which was confirmed through geoarchaeological analysis (Dunseth et al. 2019; and for more details, Butler et al. 2020). However, all studied archaeological pellets derived from securely dated midden contexts with almost no evidence for macroscopic bioturbation. The middens contained datable artifacts including pottery, coins, and glass (Tepper et al. 2018; Fuks et al. 2020), complemented by radiocarbon dates. For the dung pellet study, one pellet from each context was subdivided, half for pollen analysis and half for radiocarbon dating (Dunseth et al. 2019).

Over 50 pellets were individually analysed by the collaborating laboratories, as well as seven sediment samples from corresponding contexts. The two main archaeological assemblages came from grey ashy sediment deposits with no internal layering from two Umayyad-period midden contexts accumulated in Byzantine domestic quarters, Areas K and E. Samples included charred and uncharred archaeological pellets, corresponding sediments from the same loci from which the pellets were taken (with focus on Locus 162, Area K1, and Locus 501, Area E), and modern reference dung pellets left nearby by flocks (for more details on methodology, see Dunseth et al. 2019).

To compare botanical contents of the dung pellets with those of the middens, we used geoarchaeological techniques of Fourier transform infrared spectroscopy (FTIR, see Weiner 2010) and microremains analysis to characterize the pellets and sediments, and then compared their respective archaeobotanical proxies: pollen, phytoliths and seeds. As 
Table 2 Comparison between mineralogy, phytoliths, calcitic microremains, and pollen concentrations in dung pellets and associated sediments

\begin{tabular}{|c|c|c|c|c|c|c|c|c|}
\hline Context & Type & Mineralogy & $\begin{array}{l}\text { OM } \\
(\mathrm{LOI} \%)\end{array}$ & $\begin{array}{l}\text { Phytoliths } \\
\left(\times 10^{6} / \mathrm{g}\right)\end{array}$ & $\begin{array}{l}\text { Dung } \\
\text { spherulites } \\
\left(\times 10^{6} / \mathrm{g}\right)\end{array}$ & $\begin{array}{l}\text { Ash pseu- } \\
\text { domorphs } \\
\left(\times 10^{6} / \mathrm{g}\right)\end{array}$ & PSR & $\begin{array}{l}\text { Pollen } \\
\left(\times 10^{6} / \mathrm{g}\right)\end{array}$ \\
\hline \multicolumn{9}{|c|}{ Controls Wadi Zeitan } \\
\hline & Dung pellets & $\mathrm{Ca} \mathrm{Cl}$ (ua) Org SN O Q & $84 \pm 1$ & $71 \pm 27$ & $667 \pm 73$ & $1.5 \pm 0.3$ & $0.002 \pm 0.001$ & 0.3 \\
\hline & Sediment & $\mathrm{Ca} \mathrm{Cl}$ (ua) Org Q & $7 \pm 3$ & 0 & $0.07 \pm 0.03$ & 0 & n.a. & 0.0006 \\
\hline \multicolumn{9}{|c|}{ Archaeological samples } \\
\hline \multirow[t]{2}{*}{ L. 951} & Dung pellets & $\mathrm{Ca} \mathrm{Cl}$ (ua) Org SN O Q & $59 \pm 6$ & $13 \pm 15$ & $295 \pm 6$ & $0.3 \pm 0.1$ & $0.009 \pm 0.001$ & $2.6-15.3$ \\
\hline & Sediment & $\mathrm{Ca} \mathrm{Cl}$ (ua) SN Q G & 7 & 0.2 & 2 & 0.1 & 0.050 & n.d \\
\hline \multirow[t]{2}{*}{ L. 162} & Dung pellets & $\mathrm{Ca} C l$ (a) Org SN Ap O Q & $55 \pm 18$ & $44 \pm 30$ & $138 \pm 100$ & $6.9 \pm 8.8$ & $0.100 \pm 0.136$ & 0 \\
\hline & Sediment & $\mathrm{Ca} C l$ (a) SN Ap Ar O Q & 11 & 10 & 38 & 0.8 & 0.021 & 0.001 \\
\hline \multirow[t]{2}{*}{ L. 505} & Dung pellets & $\mathrm{Ca} C l$ (ua) Org SN Ap O Q & $37 \pm 12$ & $19 \pm 25$ & $121 \pm 40$ & $0.7 \pm 0.5$ & $0.005 \pm 0.002$ & $0.04-1.8$ \\
\hline & Sediment & $\mathrm{Ca} \mathrm{Cl}$ (ua) SN Q & 15 & 2 & 23 & 1 & 0.043 & n.d \\
\hline \multirow[t]{2}{*}{ L. 501} & Dung pellets & $\mathrm{Ca} \mathrm{Cl}$ (ua) Org SN Ap O Q G & $41 \pm 4$ & $13 \pm 10$ & $280 \pm 76$ & $0.4 \pm 0.3$ & $0.002 \pm 0.001$ & $0.3-1.1$ \\
\hline & Sediment & $\mathrm{CaCl}$ (a) O Ar Q An & 12 & 9 & 33 & 0.9 & 0.027 & n.d \\
\hline
\end{tabular}

Results given as averages with standard deviations per gram of ashed $\left(500{ }^{\circ} \mathrm{C}\right)$ sediment or dung in the case of phytoliths and calcitic microremains, and ranges for pollen. Data from Dunseth et al. (2019) and unpublished data

$\mathrm{Ca}$ calcite, $\mathrm{Cl}$ clay (altered/unaltered), $\mathrm{Org}$ organics, $S N$ sodium nitrate (nitratite), $A p$ carbonated hydroxylapatite, $A r$ aragonite, $O$ opal, $Q$ quartz, $G$ gypsum, An anhydrite

far as we are aware, the application of all these techniques had never been used before to compare dung pellets with accompanying archaeological sediments.

\section{Comparing dung pellet and sediment botanical composition: similarities and differences}

Geoarchaeological characterization of the archaeological dung pellets and sediments showed clear differences in mineralogy, loss on ignition and microremains concentrations. Microremains concentrations-most clearly dung spherulites, but also phytolith and ash pseudomorph concentrations-of intact pellets compared with associated archaeological sediments suggested a conservative maximum of 10-30\% dung-derived component in the refuse deposits at Shivta (Table 2; Dunseth et al. 2019; Butler et al. 2020). PSR values were $<0.05$ in all sediment samples, which initially suggested all archaeological sediments in our study were dung-dominated (values $<1$, cf. Gur-Arieh et al. 2013, 2014). However, the dung pellets (except those from Locus 162) presented values an order of magnitude lower than the sediments, indicating a significant addition of wood ash in the archaeological sediments.

PSR was developed to explore hearths and fire features, and thus its efficacy in exploring other archaeological contexts needs to be evaluated. We suggest that PSR should also be calibrated to the local flora if possible. Ideally, such calibrations would focus on plant species for which the periodspecific and site-specific archaeological wood charcoal record indicates common use as fuel (for changing wood use in the Byzantine-Early Islamic periods in the Negev, see Langgut et al. 2020). In the Negev, ash pseudomorphs with distinct morphologies are known from experimental ashing of several wild and cultivated (e.g. grape) plants (ZD personal observations), but not others (e.g. olive, ShahackGross and Ayalon 2013). However, absolute production and concentrations of ash pseudomorphs in archaeological/ experimental ash of Negev plant fuels is relatively unexplored and should be an important avenue for research aimed at improving the use of PSR in arid regions.

Turning to the macroscopic plant remains, similar conclusions regarding dung-derivation were evident (Table 1). The following results and discussion will focus on these, in light of the seed-based indicators for dung offered by Charles (1998), and suggested by experimental taphonomy studies on the survivability of macroscopic plant parts in the sheep/ goat gut (Valamoti and Charles 2005; Spengler et al. 2013; Valamoti 2013; Wallace and Charles 2013).

Among the macroscopic archaeological plant assemblages, there were three main similarities between the dung pellets and the middens: (1) preservation by charring; (2) local phytogeographic distribution; and (3) a strong seasonal convergence.

(1) Preservation Macroremains surviving in the archaeological sediment samples were overwhelmingly preserved by charring. Among archaeological dung pellets, macroremains were only preserved in charred pellets. This suggests that the uncharred dung pellets were not truly desiccated; they weighed less, their macroscopic 
contents appeared totally degraded and were pervaded by an unidentified white mould. The only uncharred seeds came from the modern dung pellets, which were richer than the charred archaeological pellets. The phytolith assemblage showed similar preservation equally across the charred and uncharred pellets and sediments from the same contexts. Meanwhile, pollen was preserved only in uncharred (modern and archaeological) pellets and unheated sediments, precluding the possibility of studying individual pellets by all three proxies simultaneously.

(2) Phytogeographic distribution All identified wild plant species from both dung and sediment samples grow today in the Negev, indicating local livestock grazing. Moreover, the combination of the three species, Tamarix aphylla (L.) H. Karst, Melilotus sulcatus Desf., and Medicago astroites (Fisch. \& C. A. Mey.) Trautv., found in one of the sediment samples is unique to the vegetation of the Negev Highland phytogeographic zone (Danin and Fragman-Sapir 2020+).

(3) Seasonality Both the sediment samples and the dung pellets showed a strong seasonal convergence. Spring is the flowering season of all annual species in both assemblages. Flowering times for all plant specimens identified to species overlap in March-April, indicating assemblages produced in April-June. This convergence was evident even in individual pellets.

Alongside these similarities, there are some important differences in plant remain variety between the dung pellets and sediment samples (Table 3 ) as regards (1) species richness, (2) synanthropy and (3) plant part types preserved:

(1) Richness Each three-litre archaeological sediment sample contained thousands of macroscopic plant parts, hundreds of which were identifiable and countable, representing about 50 taxa each (Table 1, ESM Table 1). The archaeological pellets yielded seeds of only half a dozen taxa. Moreover, the overall preservation of plant remains is much better in the sediment samples than in the dung pellets. These would not count as differences in and of themselves since each individual pellet

Table 3 Summary of differences between dung pellet and sediment macroremains

\begin{tabular}{lll}
\hline & Dung pellets & Sediments \\
\hline Species richness & Low & High \\
Domestic/wild & Wild & Wild, weed, domestic \\
Plant parts & $\begin{array}{c}\text { Seeds, small or } \\
\text { hard-coated }\end{array}$ & Various \\
Plant life forms & Annuals & Annuals, shrubs, trees \\
\hline
\end{tabular}

is equivalent to only a few $\mathrm{ml}$ of sediment. However, when considered together with the qualitative differences between the dung pellets' botanical contents and those of the sediments, it becomes clear that there are real species-richness differences. For instance, in the pellets, only low-lying annuals and semi-shrubs were represented, except for one Retama raetam (Forssk.) Webb seed from a modern pellet, whereas trees and shrubs were represented in the sediments. Additional qualitative differences include synanthropy and the variety of plant parts.

(2) Synanthropy In the dung pellets, only wild species were identified, whereas in the corresponding sediments domestic and weed species dominate (Table 1, Fig. 2, ESM Tables 2 and 3). Significantly, the phytolith finds indicated foddering with cereal chaff, which was not picked up by pollen or seed analysis. However, based on previous experimental studies (Valamoti and Charles 2005; Spengler et al. 2013; Wallace and Charles 2013), it is clear that the numerous well-preserved charred cereal grains and rachis fragments from the sediments did not derive directly from sheep/goat dung.

(3) Plant parts In the dung pellets, only seeds were identified, and only very small or hard coated seeds-as predicted by previous studies (Valamoti and Charles 2005; Spengler et al. 2013; Wallace and Charles 2013). In the sediments, we found all parts of cultivated cereal plants, grape skins and pedicels, lentil pods, pomegranate rinds, as well as wild species' flowers, perianths, receptacles, pods, stem segments, and leaves (ESM Table 1). In quantitative terms, of identified macroremains, seeds comprise $100 \%$ of the identified plant assemblage in the archaeological pellets, $90 \%$ in the modern pellets, and $50-60 \%$ in the sediment samples (where "seeds" include seed-containing plant parts, e.g. fertile dispersal units, achenes, mericarps and endocarps). Much of the difference is made up by grass plant parts, including rachis fragments, culm nodes and collars, grass rhizomes, as well as unquantified glume, awn, and culm internode fragments (ESM Table 1). No such plant parts were identifiable in the archaeological pellets, not even split and rough-edged ones of the type described by Valamoti (2013) in her experimental study. This might be a function of dung pellet sample size, especially since the phytoliths revealed significant presence of grass leaf/ stem and inflorescence. Regardless, the above demonstrates that seeds found in the sediments were clearly not primarily dung-derived. 


\section{Modern pellets}

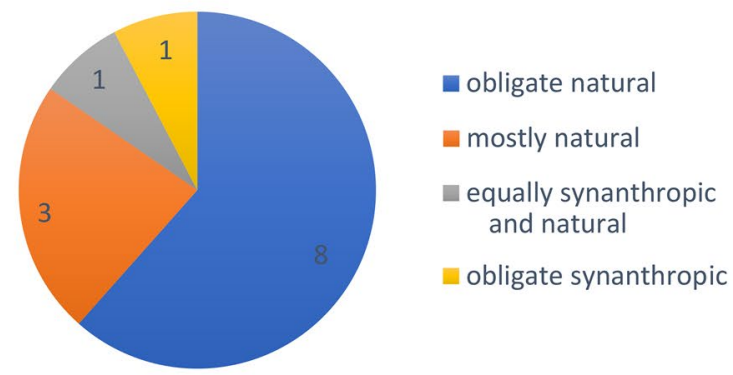

Archaeological pellets

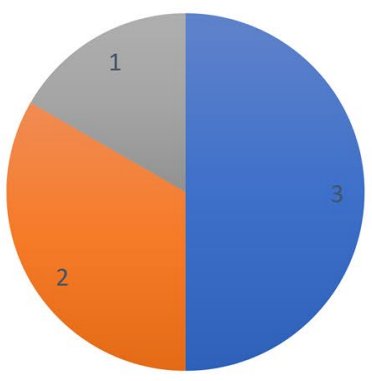

obligate natural

mostly natural

- equally synanthropic and natural

\section{Archaeological sediments}

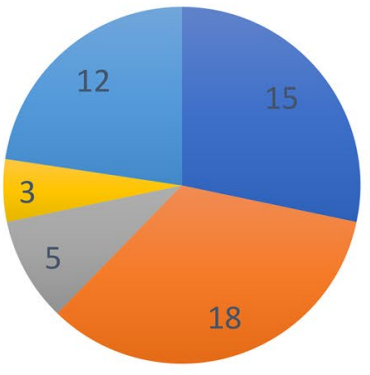

- obligate natural

mostly natural

- equally synanthropic and natural

- obligate synanthropic

abligate synanthropic/ cultivated

\section{Modern Negev Highlands}

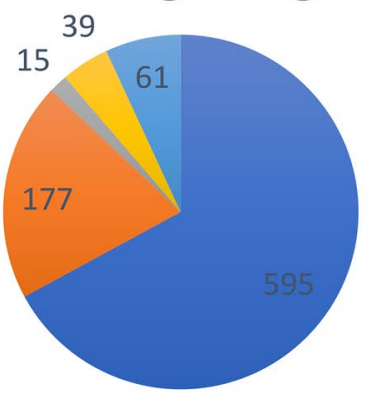

$$
\begin{aligned}
& \text { @ obligate natural } \\
& \text { mostly natural } \\
& \text { equally synanthropic } \\
& \text { and natural } \\
& \text { obligate synanthropic } \\
& \text { obligate synanthropic / } \\
& \text { cultivated }
\end{aligned}
$$

Fig. 2 Species per synanthropic group by context

\section{Assessing dung-derivation of plant remains}

A strong consilience of results from the geoarchaeological and archaeobotanical analyses precludes the possibility of a mostly dung-derived assemblage in samples studied from Shivta's Early Islamic middens. Plant remains originating in dung represent only a subset of the plant remains in the midden sediments. Interestingly, our results were mixed on Charles' (1998) indicators for dung-derived plant remains. No divergence of seasonality was found within the samples analysed for macroremains (indicator i, above); on the contrary, both sample sets displayed full convergence in late spring-early summer. Since this season also corresponds to the cereal harvest, no case can be made for dung-derived weed seeds based on the fruiting season of identified plant species from the study contexts.

However, there was presence of strictly wild plant species not associated with crop processing (indicator ii). To further demonstrate this point (beyond the discussion in Dunseth et al. 2019), we categorized all identified species according to their prevalence in human and natural environments using data adopted from Danin and Fragman-Sapir (2020+): cultivated; obligate synanthrope; mostly synanthropic; equally synanthropic and natural; mostly natural; and obligate natural (Table 1; ESM Table 2). Where identification was narrowed down to two species, we assigned synanthropic labels if both species shared the same category. Although the total number of species identified in the pellets is low, some interesting observations may be made. "Obligate natural" species comprise a relatively greater proportion of the dung pellets ( 8 of 13 and 3 of 6 in the modern and archaeological pellets, respectively) than of the sediment samples (15 of 53; ESM Table 2, Fig. 2). Although few in number, this is clearly the largest category of identified species in the archaeological pellets, but not so for the sediment samples. This suggests that many of the wild species' seeds found in the sediment samples could have derived directly from dung. On the other hand, cultivated plant parts not only dominate the sediments in terms of volume, but obligate natural species are significantly underrepresented. To demonstrate this, we compared the percentages of each synanthropic category in the archaeological sediments (from a total 53 taxa for which this categorization is possible) to those of the modern Negev Highlands (887 species) and of the Flora Palaestina region in general (2,903 species). The "cultivated" and "obligate synanthrope" categories were combined since Danin and Fragman-Sapir (2020+) do not distinguish between them (ESM Table 3). Whereas the obligate natural species comprise $67 \%$ and $71 \%$ of the modern Negev Highlands and 
Flora Palaestina region vegetation, respectively, they comprise only $28 \%$ in the archaeological sediment (Fig. 2). This further strengthens the observation that the plant assemblage in the sediment samples reflects primary human-plant interaction (e.g. crop processing and consumption) rather than secondary human-plant interaction (e.g. livestock rearing).

These finds also support the idea that plant remains indicative of ecotopes favoured by livestock can be used as an indicator for dung (Spengler et al. 2013; Bruno and Hastorf 2016). However, identifying specific indicative species is both challenging and necessary. For instance, sedges (Cyperaceae) - indicated by phytoliths in most of the study samples and by pollen in one sample-are sometimes erroneously assumed to indicate wet environments. Five species of Cyperaceae are found today in the Negev Highlands (Danin and Fragman-Sapir 2020+); they inhabit humid habitats (Cyperus laevigatus L. and C. distachyos All.), disturbed habitats (C. rotundus L.), sand dunes (C. macrorrhizus Nees) and, most commonly in the region, desert habitats (Carex pachystylis J.Gay). Except for Cyperus rotundus, which is very rare in the Negev, all the above are obligate natural species. Unlike the closely related Cyperus papyrus L., the Negev sedges are generally too small to be useful for paper-making or other economic activities, apart from $C$. distachyos. Hence, sedges are a likely dung-derived component of Negev assemblages which can be ecotypic specific, but only if identified to species. It is also important to note that any of the above habitats may be used for grazing.

Regarding the related issue of plant palatability to herbivores, one of the more surprising finds in this study was a fertile Stipa capensis dispersal unit in one of the modern dung pellets (Dunseth et al. 2019, their Fig. 4). A similar find was a focus of the debate between Miller $(1996,1997)$ and Hillman et al. (1997) who argued that ripe Stipa grains found at Abu Hureyra were one indication that the assemblage could not have originated in dung. These are sharp and dangerous to the ruminant digestive tract, and therefore avoided by herbivores and their keepers (Hillman et al. 1997). Seligman et al. (1959, p. 156) noted that avoidance of Stipa capensis in sheep is seasonal: it is eaten either during winter, before ripening, or during late spring-early summer, following seed dispersal. Since the assemblage in question was also identified to late spring-early summer, the $S$. capensis dispersal unit may have been inadvertently ingested among mostly post-dispersal plants. In addition, it is possible that Stipa spp. avoidance is specific to sheep, with hardier goats being less selective. In any case, the $S$. capensis find, recovered from inside a modern dung pellet, challenges the argument that Stipa grains may be used as an indicator of strictly human waste.

Finally, in terms of chaff:grain ratios (Charles 1998, indicator iii), the numbers of rachis segments to grains are 189:89 and 216:135 in the two sediment samples which were the focus of the macroremains analysis (Loci 162 and 501, respectively). Significantly, in Locus 501 the wheat grains are all exceedingly small, suggesting that they represent tail grains, i.e. waste products of crop processing (Hillman 1984). Hence the ratio 216:135 in this case underestimates the relative proportion of crop processing by-product to product in this sample. Yet even without correcting for tail grains, both ratios reflect a higher proportion of chaff. For unprocessed cereal ears, we would expect the ratio of rachis segments to grains to be less than $1: 2$, reflecting "on the stalk" ratios for the main identified cereal types. In Locus 501 this is the case for barley, suggesting that the plant remains there comprise a mix of barley fodder and wheat processing waste (ESM Table 1). Textual sources from Roman Palestine indicate that wheat was preferred for human consumption, and barley considered animal fodder (Safrai 1994, pp. 108-109). However, the extent to which this distinction between wheat and barley is reflected at Shivta specifically and in the Negev generally, is a question for further research.

Although not a single cereal grain or rachis fragment was found in any of the dissected dung pellets, including the modern ones, a small proportion of identified rachis segments from the archaeological sediments were covered in a fibrous matrix characteristic of dung. Hence, although no rachis segments were evident in the archaeological pellets (cf. Valamoti 2013), the above finds support the use of foddering indicated by the phytolith assemblage discussed above. Yet their rarity supports the conclusion that the dung-derived plant remains in the middens comprise only a small proportion of the overall plant assemblage. In samples from Shivta's Umayyad middens, a few intact barley grains, Malva sp. seeds, and others were found embedded in dung fragments (Figs. 3, 4). Regarding the intact barley grains in dung, it is possible that these derived from equids or camelids, since there is some archaeozoological evidence for these animals in Early Islamic Shivta (Marom et al. 2019), and equid/camelid digestion is more conducive to grain preservation (Anderson and Ertug-Yaras 1998; Hastorf and Wright 1998; Tsartsidou et al. 2008). In any case, these are the exceptions that prove the rule, that most of the plant remains from the Shivta midden samples are not directly dung-derived.

\section{Dung-derived vs. dung-related}

In assessing the archaeobotanical evidence from dung pellets and associated sediments, it is important to consider herbivore-related contributions to the assemblage that did not pass through the herbivore gut. One example is the uneaten fodder found in every animal pen, which is commonly mixed with dung for kindling (Anderson and Ertug-Yaras 1998). In 


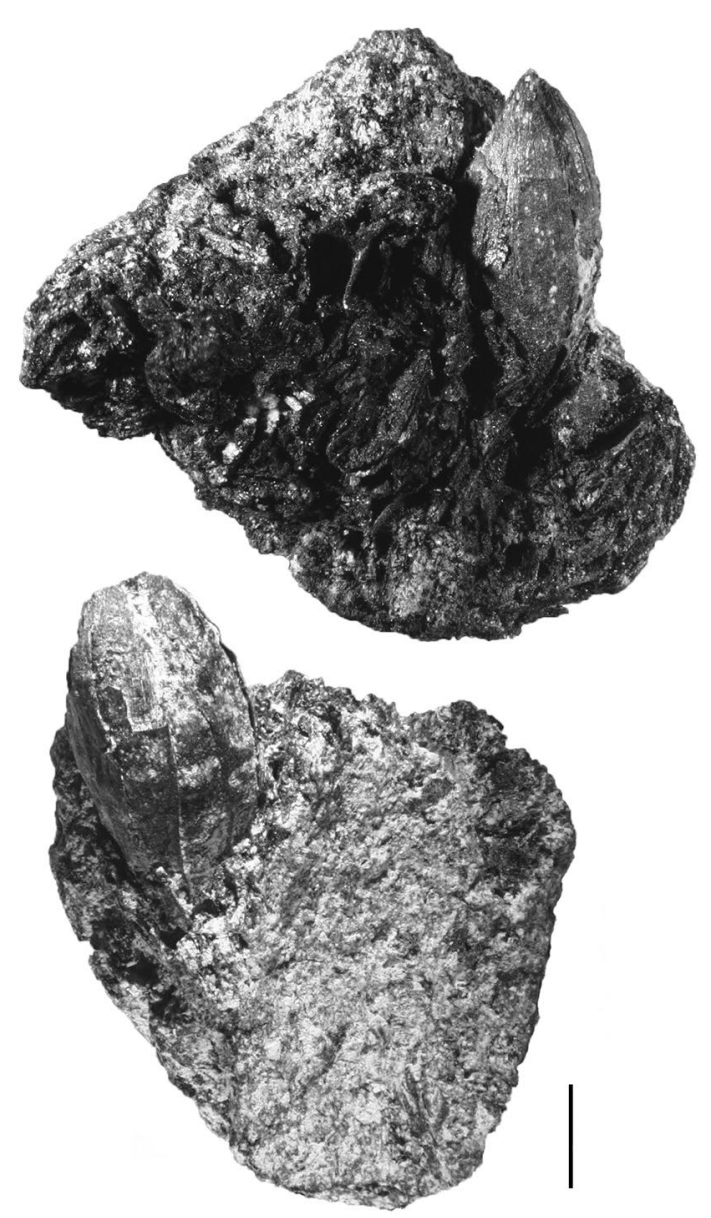

Fig. 3 Barley (Hordeum vulgare) grains embedded in dung fragments from Early Islamic middens in Shivta (Area K1, Locus 165, Basket 1673, top, and Area E, Locus 503, Basket 5016, bottom). Such clearly dung-derived plant remains are the exceptions that prove the rule; scale bar $=2 \mathrm{~mm}$
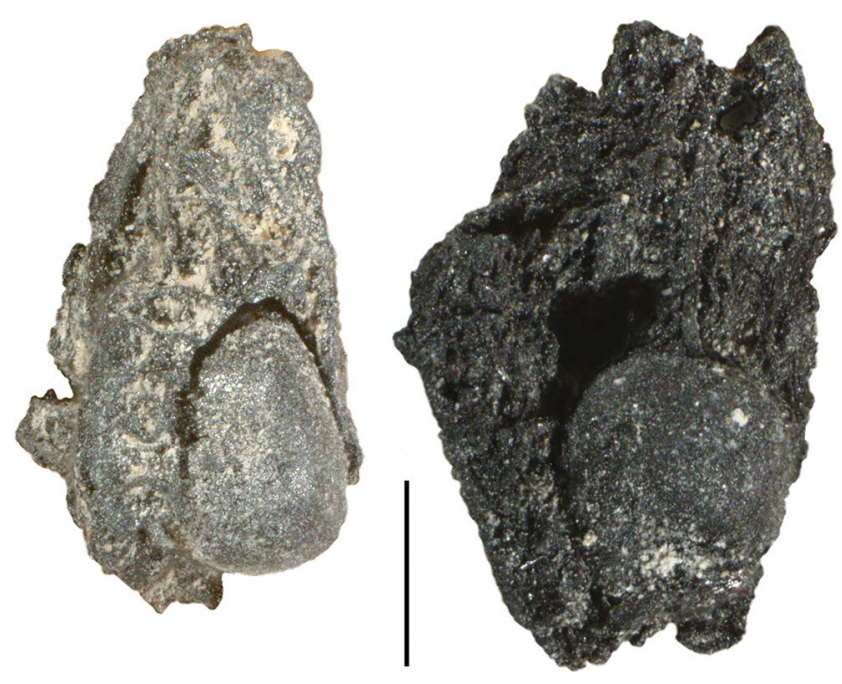

Fig. 4 Malva sp. seeds embedded in two dung fragments. Such finds are exceptional in the middens; scale bar $=1 \mathrm{~mm}$ addition, exozoochory as well as endozoochory should be considered a vector for plant depositions. For instance, the sharp and delicate Bassia muricata (L.) Asch. perianth found in one of our sediment samples (Locus 162) is unlikely to have passed through an animal's gut intact but could have been transported to the site on livestock fur. The distinction between dung-derived and dung-related is valuable in analysing archaeobotanical assemblages.

The criteria laid out by Miller and Smart (1984), strongly suggested that the Early Islamic middens of Shivta were dung-related, justifying a detailed study of the plant remains' source. This was first carried out utilizing geoarchaeological methods for characterizing deposits to infer their origin. In this case, while dung was clearly a significant component of the deposits, they were not primarily dung-derived. This conclusion was independently reached by analysis of the macrobotanical remains, presented above in terms of the criteria offered by Charles (1998) and other archaeobotanists (Valamoti and Charles 2005; Spengler et al. 2013; Valamoti 2013; Wallace and Charles 2013). The Early Islamic Shivta dumps appear to represent a mix of crop processing waste, including kitchen spillage, household waste, as well as fodder droppings and charred and uncharred dung. This supports the argument by Fuller et al. (2014) that although dung used as fuel may contribute plant remains to archaeobotanical assemblages, archaeobotanical assemblages generally reflect human plant food processing. This also raises some theoretical questions. What is at stake in the distinction between "dung-related" and "dung-derived" archaeobotanical remains? In the case of Abu Hureyra, where identification of early human cultivation was potentially jeopardized by wild gazelle dung (Hillman et al. 1997; Miller 1997), even "dung-related" may be significant. In our case-as is probably the case with most post-Neolithic dung-related assemblages in Eurasia-we are dealing with high levels of symbiotic interdependence between humans and their flocks. Indeed, many farming communities have flexible boundaries between food and fodder, and distinguishing the two in the archaeobotanical record can be very challenging (Miller 1984b; Jones 1998; Valamoti et al. 2011). If we wish to reconstruct the types of plants cultivated in an ancient farming community, it may not matter much whether some grains reached our lab because they dropped from the cook's hand and others from the goat's mouth (or gut). On the other hand, if we would like to understand how specific crops and landscapes were used by ancient peoples, assessing dungderivation is an important step.

\section{Beyond the dung debate}

The contents of dung pellets in Shivta's dumps reflect the complexity of the dung debate in archaeobotany. On one hand, they provide an important archaeological example for 
assessing dung-derived plant remains. At the same time, these finds demonstrate that dung-related assemblages in the sense of burned refuse which contains dung, is not the same thing as primarily dung-derived; the former will not necessarily reflect herbivore diet and activity in the same way as the latter. In our case, the middens' contents represented the range of items cultivated and consumed on site. Untangling the uses and depositional pathways of each remains a challenge, to which the various methodologies described above can contribute.

Addressing that challenge, the most exciting findings from our study of Shivta dung pellets and associated sediments concern the reconstruction of herding practices. Based on the multi-proxy study of plant remains we can say with confidence that the dung pellets studied were produced in April-June, after local grazing and some supplementary foddering. Our ability to pinpoint the season and grazing range within which those ancient dung pellets were produced is due to high taxonomic resolution of seed and dispersal unit identification. This study also attests to the power of the multi-proxy method because without the phytoliths, for instance, we would have incorrectly concluded that there is no evidence for foddering. The phytoliths not only proved there was foddering, but that it included cereal by-products. Meanwhile, pollen may complement macrobotanical remains in reconstructing seasonality and in comparing plant taxa found in dung with those in sediments.

The most important insight from this study concerns the value of information contained within ancient herbivore dung (also Charles 1998; Baeten et al. 2018). Each of these dung pellets was produced and deposited in a very specific moment in time, to which we can go back and reconstruct the processes that went into the pellets' formation. We should be thinking about dung as a time capsule of pastoral activity, a spatio-temporal unit of analysis, and a unique type of archaeological context with enormous potential. We can tap this potential by using multi-proxy archaeobotany applied to dung pellets to reconstruct agropastoral activity, seasonal rhythms of daily life, site formation processes, and to assist chronological fine-tuning.

\section{For future research}

The search continues for ever-improved methods of identifying herbivore dung in archaeological sites (MapDung 2020). However, we believe that the real future of archaeological dung research lies in the contents of preserved pellets. Although intact dung pellets are much rarer in the archaeological record than sediments containing dung residues, they have been found at numerous Middle Eastern and North African sites (Charles 1998; di Lernia 2001; Rosen et al. 2005; Marinova et al. 2011, 2013; Linseele et al. 2013;
Pelling 2013; Baeten et al. 2018; Rotunno et al. 2019; Dalton and Ryan 2020; Landau et al. 2020), among other regions (Spaulding 1974; Karg 1998; Ghosh et al. 2008; Kühn et al. 2013 and references therein; Spengler 2019). We hope that our collaborative multi-proxy study on dung pellets from the Shivta middens (Dunseth et al. 2019) sets a certain baseline for the study of intact dung pellets. However, the potential for reconstructing vegetation and landscape histories from herbivore dung has hardly been realized. Experiments by Schepers and van Haaster (2015) demonstrate that presence/ absence of seed categories in sheep/goat and cow dung is representative of plant community in modern grazed fields. Hence, botanical contents of archaeological dung can be an excellent source for vegetation reconstruction, at least in grazed rangelands and herd-preferred ecotypes, provided enough dung is analysed. To capitalize on this possibility, future research should focus on improving multi-proxy identification of dung pellets' botanical content, identifying the pellets' creators, producing modern reference comparisons, and expanding databases of dung pellet contents.

One way of maximizing information obtained from dung pellets will be to expand the types of proxy data retrieved for plant identification. Regarding animal diet, genome sequencing of faeces has proved useful for identifying domestic and wild taxa whose genomes have been sequenced (Poinar et al. 1998, 2001; Hofreiter et al. 2000). In our study of Early Islamic Shivta (Dunseth et al. 2019), phytoliths provided evidence for cereal foddering, which was neither picked up by pollen nor seed identifications. It will be illuminating to compare DNA evidence for cereals as an additional indicator, which may also enable identification of specific cereal species used for foddering. Meanwhile, genetic metabarcoding might be used to reveal bulk species composition (Taberlet et al. 2012). Plant identifications from DNA should complement those from seeds, pollen and phytoliths, enhancing the precision and accuracy of dietary and environmental information (van Geel et al. 2011, 2014; Gravendeel et al. 2014). Lipids, including lignin-phenols, triterpenoids and sterols, are also good markers of vegetation, especially if combined with reference samples from the sediment where these dung pellets were found (A. Sistiaga Gutiérrez, pers. comm.). Plant cuticular $\mathrm{n}$-alkane concentration patterns and distribution may be used as biosignatures for intensity of animal corralling, duration of dung deposition, and plant diet origin within dung (Égüez and Makarewicz 2018). Since the individual dung pellet is an ideal unit of analysis, one future challenge will involve maximizing the types of proxy data retrieved from a single pellet; another will involve efficient screening for preservation of contents.

Making the most of ancient dung pellets involves not only improved identification of botanical contents but also of their creators, including the animal's species and sex. Precise species identification should be possible through 
DNA analysis. In some instances this will be enhanced by the presence of hairs (such as those indicative of local black goat in the Negev) associated with the dung assemblage and often inside pellets, which can be identified morphologically and sequenced. A combination of DNA and lipid analysis may be used for sex identification, such as shotgun analysis of sex chromosome genome segments and relative quantities of testosterone (Koren et al. 2018).

Another key methodological component of both past and future dung vegetation studies is production of, and comparison to, modern reference data, including recently produced dung pellets and ecological surveys. The analysis of grazed vegetation data will benefit from incorporation of site-specific surveys and weed ecology studies (Jones 1987; Charles et al. 1997; Palmer 1998; Bogaard et al. 1999; Hodgson et al. 1999; Jones et al. 2010). One important variable in these studies is seasonality. Direct indicators of both flowering and fruiting, through extraction of both pollen and seeds from the same pellet (preserved by desiccation, waterlogging or freezing), should yield highly specific seasonal identifications. Against these, $\delta^{13} \mathrm{C}$ and $\delta^{15} \mathrm{~N}$ isotopic ratios and grass lignin structure should also be explored as proxies of seasonality (Zazzo et al. 2015; Landau et al. 2020).

The creation of micro-regional reference collections for analysing the above types of data is essential for fine-tuning the interpretation of vegetation proxies. For instance, in our study of Shivta dung pellets (Dunseth et al. 2019), we used the local botanical literature on flowering seasons to estimate fruiting season. However, the botanical literature spans a geographical area with regional variation; micro-regional data collected over several years could further refine seasonal identifications.

If enough pellets are studied from a variety of samples and contexts at a site or region using the above approach, it should be possible to accurately reconstruct ancient landscapes, grazing patterns, and animal dietary preferences. For instance, once sufficient seasonality data is collected from dung pellets at a site, seasonal grazing patterns may emerge. Meanwhile, in cases of short but steady deposition over several years, a stratigraphic seasonal sequence could help fine tune chronology. Ultimately, unpacking the contents of ancient dung pellets will inform on the physical characteristics, diet, niche, and disease agents of the ancient pellets' producers. Expanded datasets of such dung-derived information will contribute significantly to the study of ecosystem transformation as well as the longterm development of agriculture and pastoralism.

Acknowledgements This research was made possible thanks to the Rottenstreich Fellowship of the Israel Council for Higher Education (DF). The authors would like to thank Naomi Miller for conversations and information regarding the debate on dung-derived archaeobotanical assemblages, as well as Robert Spengler III, Michael Wallace, Ruth
Pelling, and other colleagues whose conversations and encouragement at the 18th IWGP meeting in Lecce contributed to the writing of this manuscript. In addition, we thank Matthew Collins and two anonymous reviewers whose comments improved this paper, and Nahshon Roche for editing assistance. We would also like to thank Ehud Weiss, Ruth Shahack-Gross, Guy Bar-Oz, Yotam Tepper, Dafna Langgut, Yoel Melamed, Don Butler, Xin Yan and Elisabetta Boaretto for all they taught us, in the course of our previous collaboration on multi-proxy dung pellet research, and in general.

Open Access This article is licensed under a Creative Commons Attribution 4.0 International License, which permits use, sharing, adaptation, distribution and reproduction in any medium or format, as long as you give appropriate credit to the original author(s) and the source, provide a link to the Creative Commons licence, and indicate if changes were made. The images or other third party material in this article are included in the article's Creative Commons licence, unless indicated otherwise in a credit line to the material. If material is not included in the article's Creative Commons licence and your intended use is not permitted by statutory regulation or exceeds the permitted use, you will need to obtain permission directly from the copyright holder. To view a copy of this licence, visit http://creativecommons.org/licenses/by/4.0/.

\section{References}

Abell JT, Quade J, Duru G, Mentzer SM, Stiner MC, Uzdurum M, Özbaşaran M (2019) Urine salts elucidate Early Neolithic animal management at Aşıklı Höyük, Turkey. Sci Adv 5:eaaw0038

Akeret Ö, Haas JN, Leuzinger U, Jacomet S (1999) Plant macrofossils and pollen in goat/sheep faeces from the Neolithic lake-shore settlement Arbon Bleiche 3, Switzerland. Holocene 9:175-182

Allen SE (2019) Context and contents: distinguishing variation in archaeobotanical assemblage formation processes at Early Halaf Fistıklı Höyük, Turkey. Veget Hist Archaeobot 28:247-262

Anderson S, Ertug-Yaras F (1998) Fuel fodder and faeces: an ethnographic and botanical study of dung fuel use in central Anatolia. Environ Archaeol 1:99-109

Babenko AN, Kiseleva NK, Plakht I, Rosen S, Savinetskii AB, Khasanov BF (2007) Reconstruction of the Holocene vegetation in the central Negev Desert, Israel, on the basis of palynological data on the Atzmaut zoogenic deposit. Russ J Ecol 38:388-397

Baeten J, Mees F, Marinova E et al (2018) Late Pleistocene coprolites from Qurta (Egypt) and the potential of interdisciplinary research involving micromorphology, plant macrofossil and biomarker analyses. Rev Palaeobot Palynol 259:93-111. https://doi. org/10.1016/j.revpalbo.2018.09.014

Ben-Yosef E, Langgut D, Sapir-Hen L (2017) Beyond smelting: new insights on Iron Age (10th c. BCE) metalworkers community from excavations at a gatehouse and associated livestock pens in Timna, Israel. J Archaeol Sci: Rep 11:411-426

Bogaard A, Palmer C, Jones G, Charles M, Hodgson JG (1999) A FIBS approach to the use of weed ecology for the archaeobotanical recognition of crop rotation regimes. J Archaeol Sci 26:1,211-1,224

Bottema S (1984) The composition of modern charred seed assemblages. In: van Zeist W, Casparie WA (eds) Plants and ancient man: studies in palaeoethnobotany. Balkema, Rotterdam, pp 207-212

Brochier JE (1983) Combustion et parcage des herbivores domestiques: le point de vue du sedimentologue. Bull Soc Préhist Fr 80:143-145

Brochier JE, Villa P, Giacomarra M, Tagliacozzo A (1992) Shepherds and sediments: geo-ethnoarchaeology of pastoral sites. J Anthropol Archaeol 11:47-102 
Brönnimann D, Ismail-Meyer K, Rentzel P, Pümpin C, Lisá L (2017) Excrements of herbivores. In: Nicosia C, Stoops G (eds) Archaeological soil and sediment micromorphology. Wiley, Hoboken, pp 55-66

Bruno MC, Hastorf CA (2016) Gifts from the camelids: archaeobotanical insights into camelid pastoralism through the study of dung. In: Capriles JM, Tripcevich N (eds) The archaeology of Andean pastoralism. University of New Mexico Press, Albuquerque, pp 55-65

Buckland PI, Buckland PC (2019) When a 'waterhole' is full of dung: an illustration of the importance of environmental evidence for refining archaeological interpretation of excavated features. Archaeometry 61:977-990. https://doi.org/10.1111/arcm.12461

Bull ID, Simpson IA, van Bergen PF, Evershed RP (1999) Muck 'n' molecules: organic geochemical methods for detecting ancient manuring. Antiquity 73:86-96

Bull ID, Lockheart MJ, Elhmmali MM, Roberts DJ, Evershed RP (2002) The origin of faeces by means of biomarker detection. Environ Int 27:647-654

Butler DH, Dunseth ZC, Tepper Y, Erickson-Gini T, Bar-Oz G, Shahack-Gross R (2020) Byzantine-early Islamic resource management detected through micro-geoarchaeological investigations of trash mounds Negev Israel. PLoS ONE. https://doi.org/10.1371/ journal.pone.0239227

Camacho M, Perri A, Reinhard K (2020) Parasite microremains: preservation, recovery, processing, and identification. In: Henry AG (ed) Handbook for the analysis of micro-particles in archaeological samples. Springer, Cham, pp 173-199. https://doi. org/10.1007/978-3-030-42622-4

Canti MG (1997) An investigation into microscopic calcareous spherulites from herbivore dungs. J Archaeol Sci 24:219-231. https:// doi.org/10.1006/jasc.1996.0105

Canti MG (1998) The micromorphological identification of faecal spherulites from archaeological and modern materials. J Archaeol Sci 25:435-444

Canti MG (1999) The production and preservation of faecal spherulites: animals, environment and taphonomy. J Archaeol Sci 26:251-258

Canti MG (2003) Aspects of the chemical and microscopic characteristics of plant ashes found in archaeological soils. CATENA 54:339-361

Canti MG, Brochier JE (2017a) Faecal spherulites. In: Nicosia C, Stoops G (eds) Archaeological soil and sediment micromorphology. Wiley, Hoboken, pp 51-54

Canti MG, Brochier JE (2017b) Plant ash. In: Nicosia C, Stoops G (eds) Archaeological soil and sediment micromorphology. Wiley, Hoboken, pp 147-154

Canti MG, Nicosia C (2018) Formation, morphology and interpretation of darkened faecal spherulites. J Archaeol Sci 89:32-45

Charles M (1998) Fodder from dung: the recognition and interpretation of dung-derived plant material from archaeological sites. Environ Archaeol 1:111-122. https://doi.org/10.1179/env.1996.1.1.111

Charles M, Jones G, Hodgson JG (1997) FIBS in archaeobotany: functional interpretation of weed floras in relation to husbandry practices. J Archaeol Sci 24:1,151-1,161

Dalton M, Ryan P (2020) Variable ovicaprid diet and faecal spherulite production at Amara West, Sudan. Environ Archaeol 25:178197. https://doi.org/10.1080/14614103.2018.1501852

Danin A, Fragman-Sapir O (2020+) Flora of Israel. https://flora.org.il/ en/plants/. Accessed 21 Oct 2020

Delhon C, Martin L, Argant J, Thiébault S (2008) Shepherds and plants in the Alps: multi-proxy archaeobotanical analysis of Neolithic dung from "La Grande Rivoire" (Isère, France). J Archaeol Sci 35:2,937-2,952. https://doi.org/10.1016/j.jas.2008.06.007
Dennell RW (1972) The interpretation of plant remains: Bulgaria. In: Higgs ES (ed) Papers in economic prehistory. Cambridge University Press, Cambridge, pp 149-159

Dennell RW (1974) Botanical evidence for prehistoric crop processing activities. J Archaeol Sci 1:275-284

Di Lernia S (2001) Dismantling dung: delayed use of food resources among early Holocene foragers of the Libyan Sahara. J Anthropol Archaeol 20:408-441

Dunseth ZC, Shahack-Gross R (2018) Calcitic dung spherulites and the potential for rapid identification of degraded animal dung at archaeological sites using FTIR spectroscopy. J Archaeol Sci 97:118-124

Dunseth ZC, Finkelstein I, Shahack-Gross R (2018) Intermediate bronze age subsistence practices in the Negev Highlands, Israel: macro- and microarchaeological results from the sites of Ein Ziq and Nahal Boqer 66. J Archaeol Sci: Rep 19:712-726

Dunseth ZC, Junge A, Fuchs M, Finkelstein I, Shahack-Gross R (2016) Geoarchaeological investigation at the Intermediate Bronze Age Negev Highlands site of Mashabe Sade. Tel Aviv 43:43-75. https ://doi.org/10.1080/03344355.2016.1161372

Dunseth ZC, Fuks D, Langgut D et al (2019) Archaeobotanical proxies and archaeological interpretation: a comparative study of phytoliths, seeds and pollen in dung pellets and refuse deposits at Early Islamic Shivta, Negev, Israel. Quat Sci Rev 211:166-185. https://doi.org/10.1016/j.quascirev.2019.03.010

Égüez N, Makarewicz CA (2018) Carbon isotope ratios of plant $\mathrm{n}$-alkanes and microstratigraphy analyses of dung accumulations in a pastoral nomadic winter campsite (eastern Mongolia). Ethnoarchaeology 10:141-158

Eliyahu-Behar A, Shai I, Gur-Arieh S et al (2017) Early bronze age pebble installations from tell es-Safi/Gath, Israel, evidence for their function and utilization. Levant 49:46-63

Evershed RP, Bethell PH, Reynolds PJ, Walsh NJ (1997) $5 \beta$-stigmastanol and related $5 \beta$-stanols as biomarkers of manuring: analysis of modern experimental material and assessment of the archaeological potential. J Archaeol Sci 24:485-495. https:// doi.org/10.1006/jasc.1996.0132

Franceschi VR, Horner HT (1980) Calcium oxalate crystals in plants. Bot Rev 46:361-427

Franceschi VR, Nakata PA (2005) Calcium oxalate in plants: formation and function. Ann Rev Plant Biol 56:41-71

Fuks D, Bar-Oz G, Tepper Y, Erickson-Gini T, Langgut D, Weissbrod L, Weiss E (2020) The rise and fall of viticulture in the Late Antique Negev Highlands reconstructed from archaeobotanical and ceramic data. Proc Nat Acad Sci 117:19,780-19,791

Fuller DQ, Stevens C, McClatchie M (2014) Routine activities, tertiary refuse and labor organization: social inferences from everyday archaeobotany. In: Madella M, Lancelotti C, Savard M (eds) Ancient plants and people: contemporary trends in archaeobotany. University of Arizona Press, Tucson, pp 174-217

Ghosh R, Gupta S, Bera S, Jiang HE, Li X, Li CS (2008) Ovi-caprid dung as an indicator of paleovegetation and paleoclimate in northwestern China. Quat Res 70:149-157

Goren Y (1999) On determining use of pastoral cave sites: a critical assessment of spherulites in archaeology. J Israel Prehist Soc 29:123-128

Gravendeel B, Protopopov A, Bull I et al (2014) Multiproxy study of the last meal of a mid-Holocene Oyogos Yar horse, Sakha Republic, Russia. Holocene 24:1,288-1,296

Gur-Arieh S, Shahack-Gross R (2020) Ash and dung calcitic microremains. In: Henry A (ed) Handbook for the analysis of microparticles in archaeological samples. Springer, Cham, pp 117147. https://doi.org/10.1007/978-3-030-42622-4_6

Gur-Arieh S, Mintz E, Boaretto E, Shahack-Gross R (2013) An ethnoarchaeological study of cooking installations in rural Uzbekistan: development of a new method for identification of fuel 
sources. J Archaeol Sci 40:4,331-4,347. https://doi.org/10.1016/j. jas.2013.06.001

Gur-Arieh S, Shahack-Gross R, Maeir AM, Lehmann G, Hitchcock LA, Boaretto E (2014) The taphonomy and preservation of wood and dung ashes found in archaeological cooking installations: case studies from Bronze and Iron Age Israel. J Archaeol Sci 46:50-67

Gur-Arieh S, Madella M, Lavi N, Friesem DE (2019a) Potentials and limitations for the identification of outdoor dung plasters in humid tropical environment: a geo-ethnoarchaeological case study from South India. Archaeol Anthropol Sci 11:2,683-2,698

Gur-Arieh S, Morandi LF, Amicone S (2019b) Heat alteration of dungtempered anthropogenic sediments: an experimental approach. Poster presented at the International Workshop on Archaeological Soil Micromorphology, 2nd-4th September, Basel (Switzerland). https://doi.org/10.13140/RG.2.2.17057.56168

Hansen AM, Walker BJ, Heinrich F (2017) 'Impressions' of the Mamluk agricultural economy: archaeobotanical evidence from clay ovens (țābūn) at Tall Hisbān (Jordan). Tijdschr Mediterr Archeol 28:58-69

Hastorf CA, Wright MF (1998) Interpreting wild seeds from archaeological sites: a dung charring experiment from the Andes. J Ethnobiol 18:211-227

Hillman GC (1973) Crop husbandry and food production: modern models for the interpretation of plant remains. Anatolian Stud 23:241-244

Hillman GC (1981) Reconstructing crop husbandry practices from charred remains of crops. In: Mercer R (ed) Farming practice in british prehistory. Edinburgh University Press, Edinburgh, pp $123-162$

Hillman GC (1984) Interpretation of archaeological plant remains: the application of ethnographic models from Turkey. In: van Zeist W, Casparie WA (eds) Plants and ancient man: studies in palaeoethnobotany. Balkema, Rotterdam, pp 1-41

Hillman GC, Legge AJ, Rowley-Conway PA (1997) On the charred seeds from Epipaleolithic Abu Hureyra: food or fuel? Curr Anthropol 38:651-655. https://doi.org/10.1086/204651

Hodgson JG, Halstead P, Wilson PJ, Davis S (1999) Functional interpretation of archaeobotanical data: making hay in the archaeological record. Veget Hist Archaeobot 8:261-271

Hofreiter M, Poinar HN, Spaulding WG, Bauer K, Martin PS, Possnert G, Pääbo S (2000) A molecular analysis of ground sloth diet through the last glaciation. Mol Ecol 9:1975-1984

Jones G (1987) A statistical approach to the archaeological identification of crop processing. J Archaeol Sci 14:311-323

Jones G (1998) Distinguishing food from fodder in the archaeobotanical record. Environ Archaeol 1:95-98

Jones G, Charles M, Bogaard A, Hodgson J (2010) Crops and weeds: the role of weed functional ecology in the identification of crop husbandry methods. J Archaeol Sci 37:70-77

Karg S (1998) Winter- and spring-foddering of sheep/goat in the Bronze Age site of Fiavè-Carera, Northern Italy. Environ Archaeol 1:87-94

Karkanas P, Goldberg P (2019) Reconstructing archaeological sites: understanding the geoarchaeological matrix. Wiley, Chichester

Koren L, Matas D, Pečnerová P, Dalén L, Tikhonov A, Gilbert MTP, Wynne-Edwards KE, Geffen E (2018) Testosterone in ancient hair from an extinct species. Palaeontology 61:797-802

Korstange MA (2005) Microfossils in Camelid dung: taphonomic considerations for archaeological study of agriculture and pastoralism. In: O'Connor T (ed) Biosphere and Lithosphere: new studies in vertebrate taphonomy. Proceedings of the 9th conference of the International Council of Archaeozoology, Durham, August 2002. Oxbow Books, Oxford, pp 69-77

Kühn M, Maier U, Herbig C, Ismail-Meyer K, Le Bailly M, Wick L (2013) Methods for the examination of cattle, sheep and goat dung in prehistoric wetland settlements with examples of the sites Alleshausen-Täschenwiesen and Alleshausen-Grundwiesen (around cal 2900 BC) at Lake Federsee, south-west Germany. Environ Archaeol 18:43-57

Lancelotti C, Madella M (2012) The 'invisible' product: developing markers for identifying dung in archaeological contexts. $\mathrm{J}$ Archaeol Sci 39:953-963

Landau SY, Dvash L, Ryan P, Saltz D, Deutch T, Rosen SA (2020) Faecal pellets, rock shelters, and seasonality: the chemistry of stabling in the Negev of Israel in late prehistory. J Arid Environ 181:104219

Langgut D, Tepper Y, Benzaquen M, Erickson-Gini T, Bar-Oz G (2020) Environment and horticulture in the Byzantine Negev Desert, Israel: sustainability, prosperity and enigmatic decline. Quat Int. https://doi.org/10.1016/j.quaint.2020.08.056

Linseele V, Riemer H, Baeten J, De Vos D, Marinova E, Ottoni C (2013) Species identification of archaeological dung remains: a critical review of potential methods. Environ Archaeol 18:5-17

Macphail RI, Courty M-A, Hather J, Wattez J (1997) The soil micromorphological evidence of domestic occupation and stabling activities. In: Maggi R (ed) Arene Candide: A Functional and Environmental Assessment of the Holocene Sequences Excavated by L. Bernabo' Brea (1940-1950). Istituto Italiano di Paleontologia Umana, Rome, pp 53-88

MapDung (2020) Dung as construction material during the emergence of animal domestication: a multi-proxy approach. https://www. mapdungproject.com/. Accessed 21 Oct 2020

Marinova E, van Loon GJM, De Meyer M, Willems H (2011) Plant economy and land use in Middle Egypt during the late Antique/ early Islamic period: archaeobotanical analysis of mud bricks and mud plasters from the area of Dayr al-Barshā. In: Fahmy AG, Kahlheber S, D'Andrae AC (eds) Windows on the African past: current approaches to African archaeobotany. Proceedings of the 6th International Workshop on African Archaeobotany, Cairo. Reports in African Archaeology 3. Africa Magna Verlag, Frankfurt am Main, pp 120-136

Marinova E, Ryan P, van Neer W, Friedman R (2013) Animal dung from arid environments and archaeobotanical methodologies for its analysis: an example from animal burials of the Predynastic elite cemetery HK6 at Hierakonpolis. Egypt Environ Archaeol 18:58-71

Marom N, Meiri M, Tepper Y, Erickson-Gini T, Reshef H, Weissbrod L, Bar-Oz G (2019) Zooarchaeology of the social and economic upheavals in the Late Antique-Early Islamic sequence of the Negev Desert. Sci Rep 9(6):702. https://doi.org/10.1038/s4159 8-019-43169-8

Matthews W (2010) Geoarchaeology and taphonomy of plant remains and microarchaeological residues in early urban environments in the Ancient Near East. Quat Int 214:98-113

Matthews W, French CAI, Lawrence T, Cutler DF (1996) Multiple surfaces: the micromorphology. In: Hodder I (ed) On the surface-çatalhöyük excavations 1993-1995. McDonald Institute for Archaeological Research, Cambridge, pp 301-342

Mentzer SM (2014) Microarchaeological approaches to the indentification and interpretation of combustion features in prehistoric archaeological sites. J Archaeol Method Theory 21:616-668

Milek KB (2012) Floor formation processes and the interpretation of site activity areas: an ethnoarchaeological study of turf buildings at Thverá, northeast Iceland. J Anthropol Archaeol 31:119-137

Miller NF (1977) Preliminary report on the botanical remains from Tepe Jaffarabad, 1969-1974 campaigns. Cahiers de la Délég Archéol Française en Iran 7:49-53

Miller NF (1981) Plant remains from Ville Royale II, Susa. Cahiers de la Délég Archéol Française en Iran 12:137-142

Miller NF (1982) Economy and Environment of Malyan, a Third Millennium B.C. Urban Center in Southern Iran. Ph.D. dissertation, 
Department of Anthropology, University of Michigan, Ann Arbor. https://deepblue.lib.umich.edu/handle/2027.42/102023

Miller NF (1983) Paleoethnobotanical results from Bendebal and Jaffarabad. Cahiers de la Délég Archéol Française en Iran 13:277-284

Miller NF (1984a) The use of dung as fuel: an ethnographic example and an archaeological application. Paléorient 10:71-79

Miller NF (1984b) The interpretation of some charred cereal remains as remnants of dung cake fuel. Bull Sumerian Agric 1:45-47

Miller NF (1988) Ratios in paleoethnobotanical analysis. In: Hastorf CA, Popper VS (eds) Current paleoethnobotany: analytical methods and cultural interpretations of archaeological plant remains. University of Chicago Press, Chicago and London, pp 72-85

Miller NF (1996) Seed eaters of the ancient Near East: human or herbivore? Curr Anthropol 37:521-528. https://doi.org/10.1086/20451 4

Miller NF (1997) On the charred seeds from Epipalaeolithic Abu Hureyra: food or fuel? Reply. Curr Anthropol 38:655-659. https ://doi.org/10.1086/204651

Miller NF, Smart TL (1984) Intentional burning of dung as fuel: a mechanism for the incorporation of charred seeds into the archeological record. J Ethnobiol 4:15-28

Miller NF, Marston JM (2012) Archaeological fuel remains as indicators of ancient west Asian agropastoral and land-use systems. J Arid Environ 86:97-103

Nicosia C, Stoops G (2017) Archaeological soil and sediment micromorphology. Wiley, Hoboken

Palmer C (1998) An exploration of the effects of crop rotation regime on modern weed floras. Environ Archaeol 2:35-48

Pelling R (2013) The archaeobotanical remains. In: Mattingly DJ (ed) The archaeology of Fazzān, vol 4: survey and excavations at old jarma (Ancient Garama) carried out by C. M. Daniels (19621969) and the Fazzān project (1997-2001). Society for Libyan Studies, London, pp 473-494

Perrotti AG, van Asperen E (2019) Dung fungi as a proxy for megaherbivores: opportunities and limiations for archaeological applications. Veget Hist Archaeobot 28:93-104

Poinar HN, Hofreiter M, Spaulding WG et al (1998) Molecular coproscopy: dung and diet of the extinct ground sloth Nothrotheriops shastensis. Science 281:402-406

Poinar HN, Kuch M, Sobolik KD et al (2001) A molecular analysis of dietary diversity for three archaic Native Americans. Proc Natl Acad Sci USA 98:4317-4322

Polo-Díaz A, Alonso Eguíluz M, Ruiz M, Pérez S, Mújika J, Albert RM, Fernández Eraso J (2016) Management of residues and natural resources at San Cristobal rock-shelter: contribution to the characterisation of chalcolithic agropastoral groups in the Iberian Peninsula. Quat Int 414:204-225

Portillo M, Kadowaki S, Nishiaki Y, Albert RM (2014) Early Neolithic household behavior at Tell Seker al-Aheimar (Upper Khabur, Syria): a comparison to ethnoarchaeological study of phytoliths and dung spherulites. J Archaeol Sci 42:107-118

Portillo M, Belarte MC, Ramon J, Kallala N, Sanmartí J, Albert RM (2017) An ethnoarchaeological study of livestock dung fuels from cooking installations in northern Tunisia. Quat Int 431:131-144

Portillo M, García-Suárez A, Klimowicz A, Barański MZ, Matthews W (2019) Animal penning and open area activity at Neolithic Çatalhöyük, Turkey. J Anthropol Archaeol 56:101-106

Portillo M, Dudgeon K, Allistone G, Aziz KR, Matthews W (2020) The taphonomy of plant and livestock dung microfossils: an ethnoarchaeological and experimental approach. Environ Archaeol. https ://doi.org/10.1080/14614103.2020.1800344

Rhode D, Madsen DB, Brantingham PJ, Goebel T (2003) Human occupation in the Beringian "mammoth-steppe": starved for fuel, or dung-burner's paradise. Curr Res Pleistocene 20:68-70
Rhode D, Madsen DB, Brantingham PJ, Dargye T (2007) Yaks, yak dung, and prehistoric human habitation of the Tibetan Plateau. Develop Quat Sci 9:205-224

Rosen SA, Savinetsky AB, Plakht Y, Kisseleva NK, Khassanov BF, Pereladov AM, Haiman M (2005) Dung in the desert: preliminary results of the Negev Holocene ecology project. Curr Anthropol 46:317-327

Rotunno R, Mercuri AM, Florenzano A, Zerboni A, di Lernia S (2019) Coprolites from rock shelters: hunter-gatherers "herding" Barbary sheep in the Early Holocene Sahara. J Afr Archaeol 17:76-94

Safrai Z (1994) The Economy of Roman Palestine. Routledge, London . https://doi.org/10.4324/9780203204863

Savinetsky AB, Babenko AN, Debella HJ et al (2012) Zoogenic deposits in rock shelters from the Old World (experience for palaeoecological purposes). In: Lefèvre C (ed) Proceedings of the General Session of the 11th International Council for Archaeozoology Conference. Archaeopress, Oxford, pp 25-31

Schelvis J (1992) The identification of archaeological dung deposits on the basis of remains of predatory mites (Acari; Gamasida). J Archaeol Sci 19:677-682

Schepers M, van Haaster H (2015) Dung matters: an experimental study into the effectiveness of using dung from hay-fed livestock to reconstruct local vegetation. Environ Archaeol 20:66-81

Seligman N, Rosensaft Z, Tadmor N, Katznelson J, Naveh Z (1959) Natural pasture of Israel: vegetation, carrying capacity and improvement (Hebrew). Sifriat Poalim, Merhavia

Shahack-Gross R (2011) Herbivorous livestock dung: formation, taphonomy, methods for identification, and archaeological significance. J Archaeol Sci 38:205-218. https://doi.org/10.1016/j. jas.2010.09.019

Shahack-Gross R (2017) Animal gathering enclosures. In: Nicosia C, Stoops G (eds) Archaeological soil and sediment micromorphology. Wiley, Hoboken, pp 265-280

Shahack-Gross R, Finkelstein I (2008) Subsistence practices in an arid environment: a geoarchaeological investigation in an Iron Age site, the Negev Highlands, Israel. J Archaeol Sci 35:965-982

Shahack-Gross R, Ayalon A (2013) Stable carbon and oxygen isotopic compositions of wood ash: an experimental study with archaeological implications. J Archaeol Sci 40:570-578

Shahack-Gross R, Marshall F, Weiner S (2003) Geo-ethnoarchaeology of pastoral sites: the identification of livestock enclosures in abandoned Maasai settlements. J Archaeol Sci 30:439-459

Shahack-Gross R, Albert RM, Gilboa A, Nagar-Hilman O, Sharon I, Weiner S (2005) Geoarchaeology in an urban context: the uses of space in a Phoenician monumental building at Tel Dor (Israel). J Archaeol Sci 32:1,417-1,431

Shahack-Gross R, Boaretto E, Cabanes D, Katz O, Finkelstein I (2014) Subsistence economy in the Negev Highlands: the iron age and byzantine/early Islamic period. Levant 46:98-117

Shillito L-M, Bull ID, Matthews W, Almond MJ, Williams JM, Evershed RP (2011) Biomolecular and micromorphological analysis of suspected faecal deposits at Neolithic Çatalhöyük, Turkey. J Archaeol Sci 38:1,869-1,877

Shillito L-M, Blong JC, Green EJ, van Asperen EN (2020) The what, how and why of archaeological coprolite analysis. Earth-Sci Rev 207:103196

Smith A, Proctor L, Hart TC, Stein GJ (2019) The burning issue of dung in archaeobotanical samples: a case-study integrating macro-botanical remains, dung spherulites, and phytoliths to assess sample origin and fuel use at Tell Zeidan, Syria. Veget Hist Archaeobot 28:229-246. https://doi.org/10.1007/s0033 4-018-0692-9

Spaulding WG (1974) Pollen Analysis of Fossil Dung of Ovis canadensis from Southern Nevada. Unpublished MS thesis, University of 
Arizona. https://repository.arizona.edu/bitstream/handle/10150 /566368/AZU_TD_BOX274_E9791_1974_309.pdf?sequence=1

Spengler RN III (2019) Dung burning in the archaeobotanical record of West Asia: where are we now? Veget Hist Archaeobot 28:215227. https://doi.org/10.1007/s00334-018-0669-8

Spengler RN III, Mueller NG (2019) Grazing animals drove domestication of grain crops. Nature Plants 5:656-662

Spengler RN III, Frachetti MD, Fritz GJ (2013) Ecotopes and herd foraging practices in the steppe/mountain ecotone of Central Asia during the Bronze and Iron Ages. J Ethnobiol 33:125-148

Taberlet P, Coissac E, Hajibabaei M, Rieseberg LH (2012) Environmental DNA. Mol Ecol 21:1,789-1,793

Tepper Y, Erickson-Gini T, Farhi Y, Bar-Oz G (2018) Probing the byzantine/early Islamic transition in the Negev: the renewed Shivta excavations, 2015-2016. Tel Aviv 45:120-152

Tsartsidou G, Lev-Yadun S, Efstratiou N, Weiner S (2008) Ethnoarchaeological study of phytolith assemblages from an agropastoral village in Northern Greece (Sarakini): development and application of a Phytolith Difference Index. J Archaeol Sci 35:600-613

Valamoti SM (2013) Towards a distinction between digested and undigested glume bases in the archaeobotanical record from Neolithic northern Greece: a preliminary experimental investigation. Environ Archaeol 18:31-42. https://doi.org/10.1179/1461410313 Z.00000000021

Valamoti SM, Charles M (2005) Distinguishing food from fodder through the study of charred plant remains: an experimental approach to dung-derived chaff. Veget Hist Archaeobot 14:528533. https://doi.org/10.1007/s00334-005-0090-y

Valamoti SM, Moniaki A, Karathanou A (2011) An investigation of processing and consumption of pulses among prehistoric societies: archaeobotanical, experimental and ethnographic evidence from Greece. Veget Hist Archaeobot 20:381-396
Van Geel B, Fisher DC, Rountrey AN et al (2011) Palaeo-environmental and dietary analysis of intestinal contents of a mammoth calf (Yamal Peninsula, northwest Siberia). Quat Sci Rev 30:3935-3946

Van Geel B, Protopopov A, Bull I et al (2014) Multiproxy diet analysis of the last meal of an early Holocene Yakutian bison. J Quat Sci 29:261-268

Wallace M, Charles M (2013) What goes in does not always come out: the impact of the ruminant digestive system of sheep on plant material, and its importance for the interpretation of dungderived archaeobotanical assemblages. Environ Archaeol 18:1830. https://doi.org/10.1179/1461410313Z.00000000022

Wattez J, Courty M-A, Macphail RI (1990) Burnt organo-mineral deposits related to animal and human activities in prehistoric caves. In: Douglas LA (ed) Soil Micromorphology: a Basic and Applied Science. Elsevier, Amsterdam, pp 431-439

Weiner S (2010) Microarchaeology: beyond the visible archaeological record. Cambridge University Press, Cambridge

Winterhalder B, Larsen R, Thomas RB (1974) Dung as an essential resource in a highland Peruvian community. Hum Ecol 2:89-104

Zazzo A, Cerling TE, Ehleringer JR, Moloney AP, Monahan FJ, Schmidt O (2015) Isotopic composition of sheep wool records seasonality of climate and diet. Rapid Commun Mass Spectrom $29: 1,357-1,369$

Publisher's Note Springer Nature remains neutral with regard to jurisdictional claims in published maps and institutional affiliations. 